\title{
ROBERT CHARLES ZAEHNER
}

Professor R. C. Zaehner, who died suddenly on 24 November 1974, was, at the time of his death, Spalding Professor of Eastern Religions and Ethics in the University of Oxford and a Fellow of All Souls. He was born on 8 April 1913 of Swiss parents who had emigrated to England. He was educated at Tonbridge School and won a classical scholarship to Christ Church. After taking a second class in Classical Moderations, he transferred to Oriental Studies, specializing in Persian, and took a first class in 1936. In the years prior to the outbreak of the second World War, he continued his study of Old and Middle Persian under Professor (later Sir Harold) Bailey. As part of his war service he spent the years 1943-7 at the British Embassy in Tehran, where his knowledge of Persian and understanding of Persia were of immense value. He made a large number of Persian friends, by whom he was regarded with enormous respect and affection. He returned to Oxford, where in 1950 he became University lecturer in Persian. The British Government again benefited from his services when, in 1951-2, he was given leave of absence and returned to Tehran as Acting-Counsellor. In 1952 he was elected to the Spalding Professorship of Eastern Religions and Ethics, which carried with it a Fellowship of All Souls. His knowledge of and interest in the study of religions, combined with his learning and his ability to read a wide range of original sources, made him particularly well-fitted and well-equipped to hold this chair, which he did with great distinction, gaining a world-wide reputation. He was elected a Fellow of the British Academy in 1966.

His contributions to the study of Zoroastrianism and comparative religion were substantial. Zurvän (1955) is a scholarly and detailed study of Zoroastrianism, and The dawn and twilight of Zoroastrianism (1961) a masterly account of the evolution of that religion. In Mysticism sacred and profound (1957), provoked by Mr. Aldous Huxley's The doors of perception, he entered the field of comparative mysticism. In the light of what Christian, Indian, and Muslim mystics say of themselves, he demolished the "platitudinous" premiss' that all mysticism is 'essentially one and the same', drawing a distinction between monism on the one hand and theistic mysticism on the other, i.e. between 'all those who see God as incomparably greater than oneself; though $\mathrm{He}$ is, at the same time, the root and ground of one's being, and those who maintain that the soul and God are one and the same and that all else is pure illusion'. It was typical, however, of Professor Zaehner, who had entered the Roman Catholic Church in 1946, that he should, while stating his own position, have expounded both points of view and left it to the reader to judge for himself on the evidence presented. His very substantial contributions to Hinduism included Hinduism (1962) and a translation and commentary of the Bhagavad-gita (1969). He also edited and contributed to The concise encyclopaedia of living faiths (1959), one of the best introductions to the subject.

In 1959 he was appointed Jordan Lecturer at the School of Oriental and African Studies. The lectures which he gave were later published as Hindu and Muslim mysticism. In 1968-9 he gave the Gifford Lectures at St. Andrews. 
Meanwhile, he was becoming increasingly interested in the borderland between the conscious and the supra-conscious, which field he explored in Drugs, mysticism and makebelieve (1972) and in his last book, Our savage God.

Professor Zaehner had a powerful and logical mind. Loose thinking and intellectual laziness were foreign to him. He was always careful to define his terms and his writing was lucid and clear. Although he approached his material with a healthy scepticism, refusing to go further than the evidence permitted, he had also the gift of insight. In his work on comparative religion, he did not fall into the trap of treating religion as a problem to be solved. Refusing oversimplification and easy solutions, he attempted to understand what gave religion power to attract assent and loyalty.

To be taught by Professor Zaehner was a stimulating experience. In spite of his duties as Spalding Professor, he continued to help in the undergraduate teaching of Persian. He did not, perhaps, suffer fools gladly, but for the serious student he would take immense pains. His obvious enjoyment of the Persian language, coupled with his insistence on sound scholarship and strict intellectual discipline, stretched his pupils and brought out their abilities. He had a strong sense of the incongruous - he was an assiduous reader of Alice through the lookingglass-and those who were privileged to work with him found him an entertaining companion, and will remember not only his scholarship and learning, but also his loyalty and the delight of sharing with him many wildly funny incidents. He was a man of strong emotions and enthusiasms, and of toughly held views, which, however, he made no attempt to impose upon others. $\mathrm{He}$ was also a man of great originality, not to say eccentricity : paradoxically it was through ' what Catholics called the normal channels of grace' that he achieved deep religious experience.

ANN K. S. LAMBTON 